Syntax Literate : Jurnal Ilmiah Indonesia p-ISSN: 2541-0849

e-ISSN : 2548-1398

Vol. 5, No. 3 Maret 2020

\title{
PENGARUH EKSTRAK BAWANG MERAH (ALLIUM CEPA L.) TERHADAP PERTUMBUHAN BAKTERI STAPHYLOCOCCUS AUREUS
}

\author{
Yadi Suryadi dan Eri Rismawati
}

Universitas Islam Al-Ihya (UNISA) Kuningan

Email: melanosit.72@gmail.com dan erirismawati@gmail.com

\begin{abstract}
This study aims to determine the presence of antibacterial effects on the bacterium Staphylococcus epidermidis. The method used in this study is an experimental method that is the type of research that provides answers to every problem that is a causal relationship. Thus providing scientific information or data that can be used to answer the problems in this study. In this study extracts from shallots with various concentrations and control groups were used, where positive control used Clindamicyn and negative control aqua dest. The results of the study note that the onion extract with various concentrations inhibits bacterial growth in the presence of a clear zone around the disc. Recapitulation of the first and second-day clear zone data obtained on average for a concentration of $20 \%$ by $0.79 \mathrm{~cm}$, for a $50 \%$ concentration by $0.82 \mathrm{~cm}$, for an $80 \%$ concentration by $1.00 \mathrm{~cm}$ and for a $100 \%$ concentration by $1.47 \mathrm{~cm}$. Thus the onion extract with various concentrations that has the highest influence is with a concentration of $100 \%$ as an antibacterial against Staphylococcus epidermidis bacteria. However, further research is needed to test the effect of antibacterial on other bacteria that are harmful to humans.
\end{abstract}

Keywords: Influence, onion extract, bacteria, Staphylococcus epidermidis.

\begin{abstract}
Abstrak
Penelitian ini bertujuan untuk mengetahui adanya pengaruh antibakteri terhadap bakteri Staphylococcus epidermidis. Metode yang dilakukan dalam penelitian ini adalah metode eksperimen yaitu jenis penelitian yang memberikan jawaban pada setiap permasalahan yang bersifat hubungan sebab akibat. Sehingga memberikan informasi atau data ilmiah yang dapat digunakan untuk menjawab permasalahan dalam penelitian ini. Dalam penelitian ini digunakan ekstrak dari bawang merah dengan berbagai konsentrasi serta kelompok kontrol, dimana kontrol positif menggunakan Clindamicyn dan kontrol negatif aquadest. Hasil penelitian diketahui bahwa ekstrak bawang merah dengan berbagai konsentrasi tertentu menghambat pertumbuhan bakteri dengan adanya zona bening di sekitar cakram. Rekapitulasi data zona bening hari pertama dan kedua diperoleh rata-rata untuk konsentrasi $20 \%$ sebesar $0,79 \mathrm{~cm}$, untuk konsentrasi $50 \%$ sebesar $0,82 \mathrm{~cm}$, untuk konsentrasi $80 \%$ sebesar $1,00 \mathrm{~cm}$ dan untuk konsentrasi $100 \%$ sebesar 1,47 cm. Dengan demikian ekstrak bawang merah dengan berbagai konsentrasi yang mempunyai pengaruh paling tinggi yaitu dengan konsentrasi $100 \%$ sebagai antibakteri terhadap bakteri Staphylococcus epidermidis. Namun demikian perlu dilakukan penelitian lebih
\end{abstract}


lanjut untuk menguji pengaruh antibakteri terhadap bakteri lain yang berbahaya bagi manusia.

Kata kunci: Pengaruh, ekstrak bawang merah, bakteri, Staphylococcus epidermidis.

\section{Pendahuluan}

Staphylococcus epidermidis (S. epidermidis) merupakan salah satu spesies dari genus bakteri Staphylococcus yang paling sering ditemui dalam kepentingan klinis. Bakteri ini adalah bakteri gram positif dan termasuk staphylococcus dengan koagulasi negatif. Sebagian besar bakteri ini adalah flora normal pada kulit dan membran mukosa manusia (Jawetz, Melnick, \& Adelberg, 1996).

Pengobatan infeksi Staphylococcus epidermidis dapat menggunakan antibiotik seperti Eritromisin yang sering diberikan untuk luka pada kulit.Yang diproduksi dengan cara yang sama (Mintarti \& Kusumah, 2017). Eritromisin merupakan antibiotik golongan makrolid yang dapat menghambat sintesis protein bakteri Gram positif seperti Staphylococcus epidermidis (CHOIROH, 2013).

Penelitian terdahulu telah menyebutkan bahwa ekstrak bawang merah (Allium cepa L.) berpengaruh terhadap pertumbuhan bakteri gram positif Staphylococus aureus dan Escherichia coli.(Charbonnier, Gertisser, Preece, Cholik, \& Budi-Santoso, n.d.). Oleh karena itu peneliti berkeinginan menindak lanjuti saran peneliti terdahulu dengan mencoba menggunakan bakteri gram positif yang berbeda yaitu Staphylococcus epidermidis, untuk mengetahui daya anti bakteri dari ekstrak bawang merah (Allium cepa L.)

Berdasarkan pernyataan di atas, maka penulis tertarik untuk melakukan penelitian mengenai bawang merah (Allium cepa L) dengan judul "Pengaruh Ekstrak Bawang Merah (Allium cepa L.) Terhadap Pertumbuhan Bakteri Staphylococcus epidermidis".

\section{Metode Penelitian}

Dalam penelitian ini metode yang digunakan dalam menguji pengaruh bawang merah terhadap bakteri Staphylococcus epidermidis menggunakan metode penelitian eksperimen, yang bertujuan untuk mengetahui sebuah informasi atau data ilmiah yang dapat digunakan untuk menjawab permasalahan dalam penelitian ini.Jenis penelitian yang digunakan adalah eksperimen. Jenis penelitian ini digunakan untuk melakukan suatu percobaan (experiment research) yang bertujuan untuk mengetahui suatu gejala atau pengaruh yang timbul terhadap variabel experiment, sebagai akibat dari adanya perlakuan tertentu dari suatu percobaan. (Sugiyono, 2018). 


\section{Hasil dan Pembahasan}

\section{Hasil Penelitian}

a. Analisis Data

Dari hasil data pengaruh ekstrak bawang merah terhadap pertumbuhan bakteri Staphylococcus epidermidis dilakukan analisis data dengan uji regreasi yang sebelumnya terlebih dahulu dilakukan uji kenormalan (normalitas data) apabila dari hasil perhitungan uji regreasi memberikan perbedaan yang bermakna, maka dilanjutkna dengan uji t-test/berpasangan (Sugiyono, 2018).

Dalam perhitungan data statistik menunjukan bahwa tidak terdapat pengaruh ekstrak bawang merah terhadap pertumbuhan bakteri Staphylococcus epidermidis dengan konsentrasi yang berbeda dan maka pada kolom $\mathrm{F}$ hitung 1,784< F table 4,964, maka H0 diterima H1 ditolak. Hipotesis yang diajukan adalah :

H0 : Ekstrak bawang merah (Allium Cepa L) tidak berpengaruh dalam pertumbuhan bakteri Staphylococcus epidermidis.

H1 : Ekstrak bawang merah (Allium Cepa L) berpengaruh dalam pertumbuhan bakteri Staphylococcus epidermidis.

Artinya ektrak bawang merah (Allium Cepa L) tidak berpengaruh dalam pertumbuhan bakteri Staphylococcus epidermidis.

Tabel 1 Hasil Analisis uji regreasi Anova Pengaruh ekstrak bawang merah (Allium cepa L) terhadap pertumbuhan bakteri Staphylococcus epidermidis.

\begin{tabular}{ccccccc}
\hline & Model & Sum of Squares & Df & Mean Square & F & Sig. \\
\hline 1 & Regression &, 309 & 1 &, 309 & 1,784 &, $211(\mathrm{a})$ \\
\hline & Residual & 1,733 & 10 &, 173 & & \\
\hline Total & 2,042 & 11 & & & \\
\hline
\end{tabular}

Berdasarkan hasil uji statistika regresi, dihasilkan nilai $\mathrm{F}$ hitung sebesar 1,784 F table 4,964, sehingga $\mathrm{F}$ hitung < F tabel $(1,784<4,964)$ Ho diterima dan H1 ditolak artinya tidak adanya pengaruh.

Tabel 2 Hasil Analisis One Sample Test Pengaruh ekstrak bawang merah terhadap pertumbuhan bakteri Staphylococcus epidermidis

\begin{tabular}{llccccc}
\hline \multirow{2}{*}{ Model } & \multicolumn{2}{c}{$\begin{array}{c}\text { Unstandardized } \\
\text { Coefficients }\end{array}$} & $\begin{array}{c}\text { Standardized } \\
\text { Coefficients }\end{array}$ & T & Sig. \\
\cline { 3 - 8 } & B & Std. Error & Beta & & \\
\hline \multirow{2}{*}{$\mathbf{1}$} &, 329 &, 195 & & 1,690 &, 122 \\
\cline { 2 - 8 } & Ekstrak bawang merah &, 285 &, 214 &, 389 & 1,336 &, 211 \\
\hline
\end{tabular}

Tabel 3 Hasil Analisis Uji t 20\% Pengaruh ekstrak bawang merah terhadap pertumbuhan bakteri Staphylococcus epidermidis

\begin{tabular}{|c|c|c|c|}
\hline $\mathrm{df}$ & $\begin{array}{l}\text { Sig. (2- } \\
\text { tailed) }\end{array}$ & $\begin{array}{c}\text { Mean } \\
\text { Difference }\end{array}$ & $\begin{array}{c}95 \% \text { Confidence Interval } \\
\text { of the Difference }\end{array}$ \\
\hline
\end{tabular}




\begin{tabular}{|c|c|c|c|c|c|c|}
\hline & Lower & Upper & Lower & Upper & Lower & Upper \\
\hline $\begin{array}{l}\text { Diameter zona hambat } \\
\text { ekstrak bawang merah } \\
\text { terhadap pertumbuhan } \\
\text { bakteri staphilococus } \\
\text { epidermidis dengan } \\
\text { konsentrasi } 20 \%\end{array}$ & 6,723 & 4 & ,000 & 1,76600 & 1,6634 & 1,8686 \\
\hline $\begin{array}{l}\text { Diameter zona hambat } \\
\text { ektrak bawang merah } \\
\text { terhadap pertumbuhan } \\
\text { bakteri staphilococus } \\
\text { epidermidis kontrol } \\
\text { positif }\end{array}$ & 30,725 & 4 & ,000 & 1,09400 & 1,0245 & 1,1635 \\
\hline $\begin{array}{l}\text { Diameter zona hambat } \\
\text { ektrak bawang merah } \\
\text { terhadap pertumbuhan } \\
\text { bakteri staphilococus } \\
\text { epidermidis kontrol } \\
\text { negatif }\end{array}$ & 13,466 & 4 & ,000 & 2,37600 & 2,0188 & 2,7332 \\
\hline
\end{tabular}

Pada tabel di atas menunjukan bahwa berdasarkan uji t-test dihasilkan nilai $t$ hitung 6,723 lebih besar dari t tabel 1,336 sehingga $t$ hitung $>t$ table $(6,723>1,336)$ artinya adanya perbedaan antara konsentrasi $20 \%$ dengan kontrol positif.

Tabel 4 Hasil Analisis Uji t 50\% Pengaruh ekstrak bawang merah terhadap pertumbuhan bakteri Staphylococcus epidermidis

\begin{tabular}{lcccccc}
\hline & \multicolumn{5}{c}{ Test Value =0 } \\
\hline & $\mathrm{T}$ & $\mathrm{df}$ & $\begin{array}{c}\text { Sig. (2- } \\
\text { tailed) }\end{array}$ & $\begin{array}{c}\text { Mean } \\
\text { Difference }\end{array}$ & $\begin{array}{c}95 \% \text { Confidence Interval } \\
\text { of the Difference }\end{array}$ \\
\cline { 2 - 7 } & Lower & Upper & Lower & Upper & Lower & Upper \\
\hline $\begin{array}{l}\text { Diameter zona hambat } \\
\text { ekstrak bawang merah } \\
\text { terhadap pertumbuhan } \\
\text { bakteri staphilococus } \\
\text { epidermidis dengan }\end{array}$ & 7,233 & 4 &, 000 & 1,76600 & 1,6634 & 1,8686 \\
konsentrasi 50\% & & & & & & \\
\hline $\begin{array}{l}\text { Diameter zona hambat } \\
\text { ektrak bawang merah } \\
\text { terhadap pertumbuhan } \\
\text { bakteri staphilococus } \\
\text { epidermidis kontrol } \\
\text { positif }\end{array}$ & & & & & & \\
\hline $\begin{array}{l}\text { Diameter zona hambat } \\
\text { ektrak bawang merah } \\
\text { terhadap pertumbuhan } \\
\text { bakteri staphilococus } \\
\text { epidermidis kontrol }\end{array}$ & 13,466 & 4 &, 000 & 1,09400 & 1,0245 & \\
\hline
\end{tabular}


Pada tabel di atas menunjukan bahwa berdasarkan uji t-test dihasilkan nilai $\mathrm{t}$ hitung 7,233 lebih besar dari $\mathrm{t}$ tabel 1,336 sehingga $\mathrm{t}$ hitung $>\mathrm{t}$ table $(7,233>1,336)$ artinya adanya perbedaan antara konsentrasi $50 \%$ dengan kontrol positif.

Tabel 5 Hasil Analisis Uji t $80 \%$ Pengaruh ekstrak bawang merah terhadap pertumbuhan bakteri Staphylococcus epidermidis

\begin{tabular}{|c|c|c|c|c|c|c|}
\hline & \multicolumn{6}{|c|}{ Test Value $=0$} \\
\hline & $\mathrm{T}$ & df & $\begin{array}{l}\text { Sig. (2- } \\
\text { tailed) }\end{array}$ & $\begin{array}{c}\text { Mean } \\
\text { Difference }\end{array}$ & $\begin{array}{r}95 \% \mathrm{Co} \\
\text { of th }\end{array}$ & $\begin{array}{l}\text { ce Interval } \\
\text { ference }\end{array}$ \\
\hline & Lower & Upper & Lower & Upper & Lower & Upper \\
\hline $\begin{array}{l}\text { Diameter zona hambat } \\
\text { ekstrak bawang merah } \\
\text { terhadap pertumbuhan } \\
\text { bakteri staphilococus } \\
\text { epidermidis dengan } \\
\text { konsentrasi } 80 \%\end{array}$ & 7,236 & 4 & ,000 & 1,76600 & 1,6634 & 1,8686 \\
\hline $\begin{array}{l}\text { Diameter zona hambat } \\
\text { ektrak bawang merah } \\
\text { terhadap pertumbuhan } \\
\text { bakteri staphilococus } \\
\text { epidermidis kontrol } \\
\text { positif }\end{array}$ & 30,725 & 4 & ,000 & 1,09400 & 1,0245 & 1,1635 \\
\hline $\begin{array}{l}\text { Diameter zona hambat } \\
\text { ektrak bawang merah } \\
\text { terhadap pertumbuhan } \\
\text { bakteri staphilococus } \\
\text { epidermidis kontrol } \\
\text { negatif }\end{array}$ & 13,466 & 4 & ,000 & 2,37600 & 2,0188 & 2,7332 \\
\hline
\end{tabular}

Pada tabel di atas menunjukan bahwa berdasarkan uji t-test dihasilkan nilai $t$ hitung 7,236 lebih besar dari t tabel 1,336 sehingga $t$ hitung $>t$ table $(7,236>1,336)$ artinya adanya perbedaan antara konsentrasi $80 \%$ dengan kontrol positif.

Tabel 6 Hasil Analisis Uji t 100\% Pengaruh ekstrak bawang merah terhadap pertumbuhan bakteri Staphylococcus epidermidis

\begin{tabular}{lcccccc}
\hline & \multicolumn{6}{c}{ Test Value $=0$} \\
\hline & $\mathrm{T}$ & $\mathrm{df}$ & $\begin{array}{c}\text { Sig. (2- } \\
\text { tailed) }\end{array}$ & $\begin{array}{c}\text { Mean } \\
\text { Difference }\end{array}$ & $\begin{array}{c}95 \% \text { Confidence Interval } \\
\text { of the Difference }\end{array}$ \\
\cline { 2 - 7 } & Lower & Upper & Lower & Upper & Lower & Upper \\
\hline $\begin{array}{l}\text { Diameter zona hambat } \\
\text { ekstrak bawang merah } \\
\text { terhadap pertumbuhan } \\
\text { bakteri staphilococus } \\
\text { epidermidis dengan }\end{array}$ & 8,113 & 4 &, 000 & 1,76600 & 1,6634 & 1,8686 \\
\hline
\end{tabular}




konsentrasi 100\%
$\begin{aligned} & \text { Diameter zona hambat } \\ & \text { ektrak bawang merah } \\ & \text { terhadap pertumbuhan } \\ & \text { bakteri staphilococus }\end{aligned}$ 30,725 $4 \quad 4 \quad, 000$
$\begin{aligned} & \text { epidermidis kontrol } \\ & \text { positif }\end{aligned}$

Pada tabel di atas menunjukan bahwa berdasarkan uji t-test dihasilkan nilai t hitung 8,113 lebih besar dari t tabel 1,336 sehingga $t$ hitung $>\mathrm{t}$ table $(8,113>1,336)$ artinya adanya perbedaan antara konsentrasi $100 \%$ dengan kontrol positif

\section{Pembahasan}

Penelitian ini bertujuan untuk mengetahui pengaruh ekstrak bawang merah terhadap pertumbuhan bakteri Staphylococcus epidermidis, dan juga untuk mengetahui pada konsentrasi berapa ekstrak bawang merah efektif terhadap pertumbuhan bakteri Staphylococcus epidermidis.

Uji kali ini dilakukan dengan menggunakan metode difusi cakram dengan media Nutrien Agar (NA).Sebelum dilakukan uji daya hambat seluruh alat dan NA disterilisasi menggunakan autoklaf dengan suhu $121^{\circ} \mathrm{C}$ selama 15 menit.

Staphylococcus epidermidis yang akan digunakan dilakukan peremajaan terlebih dahulu selama 2 × 24 jam. Pada saat akan digunakan pada uji daya hambat Staphylococcus epidermidis dibuat suspensi dengan menggunakan cairan $\mathrm{NaCl}$ fisiologis.

Uji dilakukan dengan cara menambahkan suspensi Staphylococcus epidermidis ke dalam media NA kemudian media tersebut diukur sebanyak $20 \mathrm{ml}$ dan dimasukkan ke dalam cawan petri lau ditunggu hingga memadat. Sementara itu rendam kertas cakram di masing masing konsentrasi, kontrol positif dan kontrol negatif kemudian taruh cakram diatas media NA yang telah memadat.

Cawan petri yang telah diuji dibungkus kemudian diinkubasi selama 2x 24 jam kemudian zona hambat diukur diameternya. Pengukuran diameter zona hambat dilakukan pada hari ke-2.

Data yang diperoleh berupa zona hambat yang ditunjukkan dengan daerah bening disekitar cakram, kemudian dilakukan uji ststistik dengan analisa data uji regresi untuk mengetahui apakah ekstrak bawang merah pengaruh minimum terhadap pertumbuhan Staphylococcus epidermidis. 
Hasil analisis menggunakan metode statistik dengan uji regresi didapatkan bahwa nilai F Hitung < F Tabel yang berarti setiap komposisi bawang merah Allium cepa L tidak memberikan pengaruh.

Untuk mengetahui ada tidaknya perbedaan yang signifikan antar masing masing kelompok perlakuan maka dilakukan uji Least Significant Difference (LSD). Dari hasi uji LSD diketahui bahwa masing-masing kelompok perlakuaan mempunyai perbedaan zona hambat yang signifikan.

Dari hasil penelitian dan hasil pengamatan dapat diketahui sebagai berikut:

a. Ekstrak Bawang Merah

1) Ekstrak bawang merah konsentrasi $20 \%$

Pada penelitian pengaruh ekstrak bawang merah terhadap pertumbuhan bakteri Staphylococcus epidermidis dengan konsentrasi $20 \%$, di dapatkan hasil efektif yaitu adanya pengaruh terhadap bakteri.

2) Ekstrak bawang merah konsentrasi $50 \%$

Pada penelitian pengaruh ekstrak bawang merah terhadap pertumbuhan bakteri Staphylococcus epidermidis dengan konsentrasi $50 \%$, di dapatkan hasil efektif yaitu adanya pengaruh terhadap bakteri.

3) Ekstrak bawang merah konsentrasi $80 \%$

Pada penelitian pengaruh ekstrak bawang merah terhadap pertumbuhan bakteri Staphylococcus epidermidis dengan konsentrasi $80 \%$, di dapatkan hasil efektif yaitu adanya pengaruh terhadap bakteri.

4) Ekstrak bawang merah konsentrasi $100 \%$

Pada penelitian pengaruh ekstrak bawang merah terhadap pertumbuhan bakteri staphilococus epidermidis dengan konsentrasi $100 \%$, di dapatkan hasil efektif yaitu adanya pengaruh terhadap bakteri.

5) Clindamycin (Kontrol Positif)

Pada penelitian ini menggunakan clindamycin (cair) sebagai kontrol positif. Karena clindamycin (cair) sudah terbukti akan hasilnya. Dari data penelitian di atas clindamycin cair sebagai kontrol positif di peroleh hasil yang sama efektif dengan ekstrak bawang merah dengan konsentrasi $100 \%$.

6) Aquades (Kontrol Negatif)

Dari data penelitian di atas Aquades sebagai kontrol negatif di peroleh dengan hasil yang cukup lama selama penelitian. Berbeda dengan ektrak bawang merah dan Clindamycin cair.

Hasil pengamatan yang diperoleh dari Pengaruh ekstrak bawang merah terhadap pertumbuhan bakteri Staphylococcus epidermidis, untuk konsentrasi 20\%, $50 \%$, 80\% ekstrak bawang merah berpengaruh terhadap bakteri staphilococus epidermidis. Tetapi tidak sebanding dengan konsentrasi $100 \%$ lebih efektif, dapat diketahui adanya perbedaan antara konsentrasi terhadap kontrol positif clindamysin cair yang sangat efektif. 
Hal ini di sebabkan karena jumlah dosis yang diberikan mempengaruhi kekuatan bahan uji terhadap pengaruh pertumbuhan bakteri Staphylococcus epidermidis, semakin tinggi dosis yang diberikan maka semakin efektif yang dihasilkan oleh ekstrak bawang merah.

Hasil statistik Anova pada lampiran dapat dilihat nilai $\mathrm{F}$ hitung kemudian dapat dibandingkan dengan nilai $\mathrm{F}$ tabel pada derajat pengaruh 1 dan 10 dengan tingkat kepercayaan 5\% yaitu $\mathrm{F}$ hitung pada pengaruh ekstrak bawang merah 1,784 sedangkan $\mathrm{F}$ tabel 4,964.

Pada hasil Uji t-test di dapat $\mathrm{t}$ hitung lebih kecil dari t table, maka $\mathrm{t}$ hitung untuk semua konsentrasi 1,336 dengan nilai signifikasi $0,00<0,05 \mathrm{H} 0$ : diterima dan H1 : ditolak, ini artinya bahwa tidak ada pengaruh yang nyata (signifikan) ekstrak bawang merah (Allium cepa L) terhadap pertumbuhan bakteri Staphylococcus epidermidis.

\section{Kesimpulan}

Berdasarkan hasil penelitian dan pembahasan "Pengaruh Ekstrak Bawang Merah Terhadap Pertumbuhan Bakteri Staphylococcus epidermidis", maka dapat ditarik kesimpulan bahwa ekstrak bawang merah tidak berpengaruh terhadap Pertumbuhan Bakteri Staphylococcus epidermidis. Ada perbedaan antara konsentrasi ekstrak bawang merah 20\%, 50\%, 80\%, 100\% terhadap kontrol positif yang berpengaruh terhadap Pertumbuhan Bakteri Staphylococcus epidermidis" 


\section{BIBLIOGRAFI}

Charbonnier, S., Gertisser, R., Preece, K., Cholik, N., \& Budi-Santoso, A. (n.d.). Surono (2013) Paroxysmal dome explosion during the Merapi 2010 eruption: processes and facies relationships of associated high-energy pyroclastic density currents. $J$ Volcanol Geotherm Res, 261, 260294.

CHOIROH, WIKA UMAYATUL. (2013). EFEK ANTIMIKROBA EKSTRAK DAUN SIRIH MERAH (Piper crocatum Ruiz \& Pav) TERHADAP Shigella dysenteriae SECARA IN VITRO. University of Muhammadiyah Malang.

Jawetz, E., Melnick, J. L., \& Adelberg, E. A. (1996). Mikrobiologi Kedokteran.(diterjemahkan oleh Edi Nugroho dan RF Maulany). Penerbit Buku Kedokteran EGC. Jakarta.

Mintarti, Indriana Satya, \& Kusumah, Slamet Hadi. (2017). KAJIAN AKTIVITAS ANTIMIKROBA MONOASILGLISEROL (MAG) DAN MONODIASILGLISEROL (MDAG) DARI MINYAK KELAPA DAN MINYAK INTI SAWIT. Syntax Literate; Jurnal Ilmiah Indonesia, 2(2), 65-76.

Sugiyono. (2018). Metode penelitian pendidikan pendekatan kuantitatif, kualitatif, dan $R \& D$. 